Bartın Üniversitesi

Eğitim Fakültesi Dergisi

Cilt 5, Sayı 2, s. 459 - 477, Haziran 2016 BARTIN - TÜRKIYE

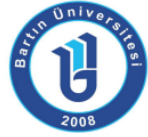

ISSN: 1308-7177
Bartin University

Journal of Faculty of Education

Volume 5, Issue 2, p. 459 - 477, June 2016

BARTIN - TURKEY

Doi: 10.14686/buefad.v5i2.5000175962

\title{
Algılanan Örgütsel Adaletin Öğretmenlerin İşe Yabancılaşma Düzeylerine Etkisi
}

Mehmet KURTULMUŞ, Yrd. Doç. Dr., Harran Üniversitesi, Eğitim Fakültesi, kurtulmus2012@gmail.com

Hüseyin KARABIYIK, Arş. Gör., Dicle Üniversitesi, Ziya Gökalp Eğitim Fakültesi, hsynkrbyk@gmail.com

Öz: Bu araştırmanın amacı, algılanan örgütsel adaletin öğretmenlerin işe yabancılaşma düzeylerine etkisini incelemektir. Araştırma tarama modeliyle gerçekleştirilmiştir. Araştırmanın evrenini Diyarbakır ili resmi liselerde görevli 302 öğretmen oluşturmaktadır. Örneklem seçkisiz örneklem alma yöntemiyle belirlenmiştir. Araştırmanın verileri örgütsel adalet ve işe yabancılaşma ölçekleri ile toplanmıştır. Araştırmada, cinsiyet değişkenine göre öğretmenlerin örgütsel adalet algılarının anlamlı bir şekilde farklılaşmadığı tespit edilmiştir. Yaş değişkenine göre ise öğretmenlerin örgütsel adalet algılarının anlamlı bir şekilde farklılaştığı görülmüştür. Ayrıca, örgütsel adalet değişkenin işe yabancılaşma değişkenini anlamlı bir şekilde yordadığı tespit edilmiştir. Bu sonuç doğrultusunda, yöneticilerin okulun imkanlarını tüm personele adil bir biçimde kullandırmaları ve çalışanlar arasında taraf tutmamaları gibi eylemlere/yönetsel uygulamalara dikkat etmelerinin önemli olduğu söylenebilir.

Anahtar Kelimeler: örgütsel adalet, yabancılaşma, işe yabancılaşma, öğretmen, lise

\section{The Effect of Perceived Organizational Justice to Work Alienation Level}

\begin{abstract}
The purpose of this study is to determine the effect of perceived organizational justice to work alienation level. The research carried out with survey model. 302 teachers who are in charge at official high schools in Diyarbakır, Turkey constituted the sample of the study. The sample was set with random sampling method. The data of research were collected with organizational justice and work alienation scales. In the research, it was understood that teachers' perceptions regarding organizational justice didn't differ significantly according to gender variable. According to age variable, it was understood that teachers' perceptions regarding work justice differed significantly. Besides, that organizational justice variable predicted organizational alienation variable significantly was found out. In acoordance with this result, it is important to say that administrators make all staffs use the school's all opportunities justly and pay attention to actions/managerial implementations like not taking sides among employees.
\end{abstract}

Key Words: organizational justice, alienation, work alienation, teacher, high schools 


\section{GíRiş}

Adaletin bireyin olduğu her yerde en önemli unsurlardan biri olduğu söylenebilir. Birey ve toplum yaşamının düzenli bir şekilde ilerlemesinde rol oynayan adalet, bireyin günlük yaşamının önemli bir bölümünü geçirdiği örgütlerde de dikkate değer bir unsurdur. Örgütlerin gelişerek varlığını devam ettirmesinin ön koşullarından birinin adalet olduğunu söylemek mümkündür. Bu bağlamda, örgütsel adaletin bir örgütün yaşaması ve gelişmesindeki önemli bir örgütsel davranış konusu olduğu açıktır (Titrek, 2009a). Örgütsel adaletin tüm örgütler için önemli ve dikkate değer bir olgu olduğu söylenebilir. Bu anlamda, örgütsel adaletin işletme örgütlerinde olduğu kadar eğitim örgütlerinde de dikkate değer bir kavram olduğu düşünülmektedir. Zira eğitim örgütlerinde örgütsel adaletin çalışanların performansını, iş doyumunu, bağııı̆̆ını, motivasyonunu ve verimini etkilediği söylenebilir (Özgan ve Bozbayındır, 2011). Adalet algısı, genellikle çalışanların bağlıık, doyum ve iyi oluşlarına katkı olarak görülmektedir (Gilliland ve Chan, 2001'den aktaran: Nair ve Vohra, 2010).

Örgütsel adaletin örgütsel bağlılık, iş doyumu gibi değişkenlerle ilişkili olduğundan hareketle, ilgili konunun örgütler için son derece olduğu söylenebilir (DeConnick ve Dean Stilwell, 2004). Örgütlerin uzun süreli varlıklarını devam ettirebilmeleri için çalışanlara yönelik uygulamalarında adalete riayet etmelerinin önemli olduğu düşünülmektedir. Çalışanlar sahip oldukları bilgi, birikim ve becerileri örgüte taşırken katkılarının karşılığını adil bir biçimde almak, görmek isterler (Çırak ve Atanur Baskan, 2015). Insanlar adil davranılmayı beklemekteler ve onlar kendilerine adil davranılmadığını gözlemledikleri zaman sistemlerine karşı büyük bir şok deneyimlemektedirler (Greenberg, 2004). Örgütlerinde adil bir yönetim anlayışının olmadığına inanan çalışanların örgütün amaç ve değerlerini tam olarak benimsemeleri ve örgütlerine katkı sağlamalarının kaçınılmaz bir şekilde azalacağı öngörülmektedir. Sookoo'ya (2014) göre çalışanlar beklentilerinin karşılanmasında başarısızlık görürse yabancılaşma yaşayabilirler.

Örgütsel adalet teorisi, örgütte çıktıların çalışanlara dağıtımında adil prosedürlerin kullanılacağına ve yöneticilerinin kendilerine adil davranmadığını algıladıklarında çalışanların örgüte katkı sağlamayacağını açıklamaktadır (George ve Jones, 2008'den aktaran: Güzel ve Ayazlar, 2014). Çalışanlar her bir yön itibarıyla kendilerine adil davranıldığına inandıklarında, daha fazla pozitif tutum ve davranışlar göstermeye yatkın olurlar (Sookoo, 2014). Çalışanların adalete olan inancı ve güveni onların örgüte bağılığından iş tatminine, motive olma ve güven duymalarından örgüt amaçlarına katkıda bulunmaya kadar birçok alanda gönüllü katılımlarını sağlayacaktır (Demirel ve Seçkin, 2011).

Bireyler, çevrelerinde özellikle çalıştıkları örgütlerdeki olup biten olayları adalet açısından değerlendirmekte, örgütlerindeki çeşitli karar, düzenleme ve uygulamalardan etkilenebilmektedirler (İyigün, 2012). Bu etkilenmeler hem olumlu hem olumsuz olabilmektedirler. Bireyin amaçları ile örgüt amaçları arasında dengenin kurulmasında, işgücü devir hızının düşürülmesinde, çalışan verimliliğinin etkin olarak sağlanmasında en önemli faktörlerden biri çalışanların örgütsel adalet düzeyleridir (Örücü ve Özafşarlıoğlu, 2013). Çalışanlar iş hayatında kendilerine adil davranıldığını algıladıklarında, onların hem yüksek örgütsel bağlılık göstermeleri hem de yöneticilerinden daha fazla memnun olmaları mümkündür (DeConnick ve Dean Stilwell, 2004).

Adalet kişilerarası ilişkileri etkileyen önemli unsurlardan biridir (Yılmaz, 2010; Bal, 2014). Çalışanlar diğer çalışanlarla kendisini mukayese eder ve burada eşitsizlik, haksızlık hissettiği zaman örgütten ve örgüt amaçlarını gerçekleştirmekten fiziksel ve duygusal olarak uzaklaşmaya başlar (Ay ve Koç, 2014). Çalışanlar adil olmayan uygulamaları algıladıklarında, devamsızlık, sabotaj, düşük örgütsel bağlılık, düşük performans, düşük iş doyumu, düşük 
verimlilik gibi olumsuz davranışlara meyledebilirler (Charbonneau, 1996; Colquitt, Conlon, Wesson, Porter ve Yee Ng, 2001; İyigün, 2012; Leck, Saunders ve Konovsky, 2000).

Araştırmalar iş yerinde algılanan adaletin, çalışanların tutum ve davranışlarını etkilediğini ortaya koymaktadır. Bireylerin örgüt içinde adaletsizliğe kayıtsız kalmadıkları söylenebilir. Çalışanlar algıladıkları örgütsel adalet düzeyine göre bilişsel ve davranışsal düzeyde tepkiler ortaya koyabilmektedirler (Bal, 2014). Bu doğrultuda, mevcut araştırmada öğretmenlerin örgütsel adalet algısının düşük olmasının onların işine karşı yabancılaşma duygusuna yol açabileceği düşünülmektedir. Örgütsel adalet yabancılaşmayı etkileyen dinamik faktörlerden biridir (Sookoo, 2014). Algılanan adaletsizlik, davranışsal ve tutumsal sonuçlar doğurmakla birlikte aynı zamanda örgüte karşı yabancılaşma davranışları oluşturabilmektedir (Yıldız, Akgün ve Yıldız, 2013). Olumsuz örgütsel adalet algısına sahip çalışanlar devamsızlık yapabilmekte ve örgütlerine yabancılaşabilmektedirler (İyigün, 2012). Çalışanlar kendilerine adil davranılmadığını anladıklarında, işe yönelik katkılarını azaltabilmekte veya örgütlerinden ayrılarak adaletsizlikten uzaklaşmaktadırlar (Cowherd ve Levine, 1992).

Öğretmenlerin işe yabancılaşması bireyin kendini ve kurumunu önemli ölçüde etkileyebilecek bir sorundur. İşe yabancılaşma tutumsal bir yapı olmasına rağmen, yine de çalışma gayreti ve ortamlarına isteksiz ve katılımsız bir şekilde karşılık verme ile ilgili genel bir eğilimi temsil edebilmektedir (Hascher ve Hagenauer, 2010). Mesleğine yabancılaşmış öğretmenin, öğrenme ve kişilik gelişimi bakımından kritik dönemdeki öğrencilere yararlı olmaları mümkün görünmemekte ve başarısız olacağını düşündüğü için de sorumluluk almaktan kaçınmaktadır (Yıldız, Akgün ve Yıldız, 2013). Eğitim örgütlerinde yabancılaşma, eğitimin giderek sıkıcı ve zevksiz bir etkinlik haline gelmesine neden olabilir (Eryılmaz ve Burgaz, 2011). Öğretmenin işine yabancılaşması, işini etkileyebileceği gibi, ilişkilerini de etkiler ve bir bütün olarak yaşama bakışını, işine yaklaşımını değiştirebilmektedir (Elma, 2003). Öğretmenlerin mesleklerinden soğumaları, onların derslere ve öğrencilere, eğitsel süreçlere karşı ilgi duymamaları, eğitsel süreçlerden uzaklaşmaları gibi durumlar yabancılaşmanın bir yansıması olarak görülebilir (Yıldız, Akgün ve Yıldız, 2013). Yabancılaşma benlik duygusunun, ticari hedefin, işgören davranışlarının ve sosyal ağların altını oyan bir olgudur (Banai ve Reisel, 2007).

Eğitim örgütleri günden güne değişen ve büyüyen örgütlerdir. Bu tür örgütlerde, çalışanların işe yabancılaşma duygusu yaşamalarının önü açıktır. Bununla birlikte, eğitim örgütlerinin başarıya ulaşmalarında özellikle öğretmenlerin görev ve sorumluluklarının önemli yeri vardır. İşine yabancılaşan öğretmenin kendini hem zihnen hem de davranışsal olarak okuluna katkı sağlaması çok zordur. Zira yabancılaşma negatif sonuçlarla ve bir takım problemlerle özdeşleştirilmektedir (Sookoo, 2014).

Araştırmalar, örgütsel adalet algısının birçok bireysel ve örgütsel çıktı ile ilişki içerisinde olduğunu ortaya koymaktadır. İşletme örgütlerinde örgütsel adaletin iş doyumu (Özer ve Urtekin, 2007), iş tatmini (Fischer, 2004; Folger ve Konovsky, 1989; Lam, Schaubroeck ve Aryee, 2002; Söyük, 2007; Yürür, 2008), örgütsel özdeşleşme (Cüce, Güney ve Tayfur, 2013), örgütsel bağlılık (Altaş ve Çekmecelioğlu, 2015; Bakhshi, Kumar ve Rani, 2009; Bal, 2014; Fischer, 2004; Folger ve Konovsky, 1989;), örgütsel destek (DeConnick, 2010), örgütsel sinizm (Çağ, 2011), işten ayrılma niyeti (Choi, 2011; Çağ, 2011; DeConnick ve Dean Stilwell, 2004; Güzel ve Ayazlar, 2014; Owolabi,2012, Örücü ve Özafşarlıoğlu, 2013), örgütsel sinizm (Çağ, 2011; Güzel ve Ayazlar, 2014), yabancılaşma (Ceylan ve Sulu, 2011; Nair ve Vohra, 2010; Sookoo, 2014) gibi değişkenlerle ilişkili olarak çalışıldığı görülmektedir.

Eğitim örgütlerinde ise, örgütsel sinizm (Çetin, Özgan ve Bozbayındır, 2013), örgütsel adanmışlık (Babaoğlan ve Ertürk, 2013), örgütsel bağlılık (Altaş ve Çekmecelioğlu, 2015; Ay ve 
Koç, 2014; Doğan, 2008; Selvitopu ve Şahin, 2013;), örgütsel özdeşleşme (Başar, 2011), iş tatmini (Altaş ve Çekmecelioğlu, 2015; Başar, 2011), örgütsel vatandaşlık davranışları (Baş ve Şentürk, 2011; Polat ve Celep, 2008; Yılmaz ve Taşdan, 2009), örgütsel güven (Baş ve Şentürk, 2011; Polat, 2007; Polat ve Celep, 2008;), liderlik sitilleri (Oğuz, 2011), örgütsel sessizlik (Ünlü, Hamedoğlu ve Yaman, 2015) değişkenleri ilişkili çalışılmıştır. Bununla birlikte, örgütsel adaletin çeşitli demografik değişkenler açısından da incelendiği görülmektedir (Aydın ve KaramanKepenekçi, 2008; Titrek, 2009b; Taşdan, Oğuz ve Ertan-Kantos, 2006; Tan, 2006; Yılmaz, 2010).

Araştırmalar incelendiğinde, örgütsel adalet ile işe yabancılaşma arasındaki ilişkinin işletme örgütlerinde çalışıldığı görülmektedir (Ceylan ve Sulu, 2011; Nair ve Vohra, 2010; Sookoo, 2014). Bununla birlikte, eğitimde önemli bir yere sahip olan işe yabancılaşma sorunun örgütsel adalet bağlamında incelenmediği görülmektedir. Bu nedenle, sürekli bir değişim içinde olan okullarda çalışan öğretmenlerin adalet algıları ile işe yabancılaşma düzeylerinin incelenmesinin alana önemli katkılar sağlayacağı öngörülmektedir. Yine, öğretmenlerin işe yabancılaşmasına etki eden bir unsurun tespit edilmesiyle yöneticilere de olumlu katkı sağlayacağı söylenebilir. Yöneticilerin örgütsel adalet algısı ile işe yabancılaşma düzeyi ilişkisini fark etmeleri onların yönetim uygulamalarında daha adaletli olmasında önemli bir rol oynayabilir.

\section{1. Örgütsel Adalet}

Örgüt ortamlarındaki geleneksel adalet görüşleri, bir ilişkinin doğruluğunu değerlendirmede temel olan bazı karşılaştırma standartlarına yönelik çalışan katkılarının çıktılara nispi oranı üzerine odaklanmıştır (Greenberg, 1986). Sookoo'ya (2014) göre örgütsel adalet yönetici ve işverenlerin davranışları, ücret ve ödüllerin verilmesini sağlayan prosedürler gibi birçok özelliği içeren çok yönlü bir kavramdır. Örgütsel adalet adil olma algısına işaret eder ve genel anlamda ürünlerin ve sürecin adil bir şekilde paylaşılabilmesini içerir (Nair ve Vohra, 2010). Eğer çalışan oranın eşit olmadığını algılarsa, çalışanın algıları doğrultusunda çabasını ya da katkılarını ayarlayama yolu ile eşitsizliği azaltmayı deneyeceği farzedilir (Choi, 2011). Örgütsel adalet işyerini direk etkilediği için hakkaniyeti tanımlamada kullanılan bir terimdir. Özellikle, örgütsel adalet çalışanların işlerinde kendilerine adil davranılıp davranıımadığını karar verdikleri ve bu kararların işle alakalı diğer değişkenleri etkilediği yaklaşımlarla ilgilidir (Moorman, 1991).

Örgütsel adalet ile ilgili literatür incelendiğinde, örgütsel adaletin hem tek hem de birden fazla boyutla çalışıldığı görülmektedir. Bu araştırmada örgütsel adalet tek boyutlu incelenmiştir. Ancak, mevcut araştırmada dağıtımsal, işlemsel ve etkileşimsel olmak üzere örgütsel adaletin farklı boyutlarına da değinilmiştir.

Dağıtımsal adalet işle ilgili kabul edilen performansın değerlendirilmesinin doğruluğuna odaklanır (Greenberg, 1986). Dağıtımsal adalet çalışanların işyeri ile değiş tokuş ilişkilerinde elde ettiği ücret, ödül, terfi gibi durumları içine alan kararlara yönelik algıladıkları adiliyet olarak açıklanır (Sookoo, 2014). Dağıtımsal adalet çıktıları algılanan adalet ile ilgili olduğu için, çıktıların dağıımının ayrılmaz bir parça olduğu örgüt ortamında güçlü etkilere sahip olma potansiyeline sahiptir (Choen-Charash ve Spector, 2001).

İşlemsel adalet daha çok sistemin ya da örgütsel özelliklerin değerlendirilmesi ile ilgilidir (Folger, 1989). İşlemsel adalet görüşü oranları belirlemede kullanılan prosedürlerin değerlendirilmesindeki hakkaniyete odaklanır (Greenberg, 1986). İşlemsel adaletin temel bir yanı paydaşların girdi veya çıktı üzerinde bir söz sahibi olmalarına imkan vermesidir. Bu nedenle çıktı katılımcılar için memnuniyet verici olmasa bile, süreçte söz hakkı verilmesi bu memnuniyetsizliği azaltabilir (DeConinck, 2010). 
İşlemsel adaletin aksine, etkileşimsel adalet karşılıklı etkileşimin daha az biçimlendirilmiş/resmileştirilmiş yanlarını içinde barındırır (DeConinck, 2010). İşlemsel adaletin genişletilmiş şekli olan etkileşimsel adalet örgütsel uygulamaların insan boyutuyla yani adaletin alıcılarına yönelik yönetimin davranış tarzı ile ilgilidir (Choen-Charash ve Spector, 2001).

\section{2. İşe Yabancılaşma}

Illk yılları itibarıyla yabancılaşma öncelikle, insanın kendi üretim eyleminden yabancılaşması olarak görülmüş; ancak, daha sonraları kavram biraz daha genişletilerek, insanın hayattan, kendinden ve öteki insanlardan yabancılaşması olarak kullanılmıştır (Esin, 1982; Fromm, 1973; Nettler, 1957). Işse yabancılaşma, kişinin öz imajı ve hem iş içi hem de iş dışı sosyal ilişkileri üzerinden genellenebilecek bir psikolojik kopuş/çözülme durumudur (Banai ve Reisel, 2007). Bu anlayış doğrultusunda, işe yabancılaşmanın işlemsel bir tanımı işten, ortamdan ya da kendinden soğuma ya da kopukluk şeklinde yapılabilir (Nair ve Vohra, 2010). Yabancılaşma bireyin sosyal ve kültürel katılımlardan dışlanması veya kendini dışlamasını yansıtan gergin olma veya rahat olmama hissidir (Hajda, 1961). Yabancılaşmanın ayrılma veya uzaklaşma, düş kırıklığı ya da gerginlik şeklinde ortaya çıkan bir durum olarak da görülmektedir (Hirschfeld ve Feild, 2000; Hoy, Blazovsky ve Newland, 1983; Lang, 1985; Yadav ve Nagle, 2012;). Yabancılaşma, ilk olarak dünyaya ait şeylerden, ikinci olarak insanlardan ve üçüncü olarak diğer insanalar tarafından idare edilen dünyaya ait fikirlerden yoğun bir şekilde uzaklaşmayı içerir (Horowitz, 1966). Seeman yabancılaşmaya sosyo psikolojik bir görüm kazandırarak (Tezcan, 1991) toplum içinde hareket eden bireyin kişisel açıdan yabancılaşması şeklinde incelemiştir (Seeman, 1959).

İse yabancılaşma işgörenin örgütteki konumuyla alakalı yaşadığı hayal kırıklığı olarak açıklanır (Hoy, Blazovsky ve Newland, 1983). Hirschfeld ve Feild de (2000) yabancılaşmayı, bireyin iş dünyasından ilgisini kesmesi, uzaklaşması olarak tanımlar. İşe yabancılaşma, çalışanın kendi içinde yaşadığı psikolojik bir olgudur (Kanungo, 1979). Bu doğrultuda, işe yabancılaşma genel anlamda çalışanın işine yönelik coşkusunu ve bağlıı̆ını yitirdiğinin göstergesi olan genel bir tutumu ifade etmektedir (Hirschfeld vd., 2000). İşe yabancılaşma, çalışanın işini anlamsız bulması; örgütünde kurduğu ilişkilerden doyum sağlayamaması; kendisini yalnız, yetersiz, güçsüz görmesi; geleceğe ilişkin umutlarını yitirmesi ve kendisini sistemin basit bir çarkı olarak algılaması şeklinde de tanımlanabilir (Elma, 2003). Yabancılaşma işte ve iş dışında kişinin kendi gereksinimlerinden ve diğer insanlardan uzaklaşma hissini yansıtır (Lang, 1985). İşe yabancılaşma, çalışanın işine yönelik geliştirdiği, içinde bıkkınlığın, yorgunluğun, soğukluğun, düş kırıklığının barındığı bir çeşit sosyo psikolojik bir durumdur. Bir diğer ifadeyle, işin çalışanın beklentilerinin ötesinde kalması, standartlaşması, durağanlaşması veya işin yapısından/kendinden ziyade çalışanın işinde yol yorgunluğuna düşmesi, işine bakışının matlaşması, pörsümesi neticesinde ortaya çıkan ve genellikle çalışanı olumsuz etkileme gücüne sahip iş temelli sosyo psikolojik bir durumdur.

\subsection{Araştırmanın Amacı}

$\mathrm{Bu}$ araştırmanın temel amacı, algılanan örgütsel adaletin öğretmenlerin işe yabancılaşma düzeylerine etkisini incelemektir. Bu amaç doğrultusunda, aşağıdaki alt amaçlara cevap aranmıştır.

1- Cinsiyete göre öğretmenlerin örgütsel adalet algıları anlamlı bir şekilde farklılaşmakta mıdır?

2- Yaşa göre öğretmenlerin örgütsel adalet algıları anlamlı bir şekilde farklılaşmakta mıdır?

3- Algılanan örgütsel adalet öğretmenlerin işe yabancılaşma düzeylerini anlamlı bir şekilde etkilemekte midir? 


\section{YÖNTEM}

\subsection{Araştırmanın Modeli}

Araştırma tarama modeliyle gerçekleştirilmiştir. Tarama modeli, çok sayıda elemandan oluşan bir evrende, evren hakkında genel bir yargıya varma amacıyla evrenin tümünün ya da bir grup örneklem üzerinde yapılan düzenlemeleri içerir (Karasar, 2006).

\section{2. Örneklem}

Araştırmanın örneklemini Diyarbakır ili resmi liselerde görevli seçkisiz örneklem alma yöntemiyle belirlenen 302 öğretmen oluşturmuştur. Araştırma her ne kadar seçkisiz örneklem alma yöntemiyle gerçekleştirilse de örneklemin cinsiyet ve yaş değişkenine göre dağılımının çeşitliğine dikkat edilmiştir. Araştırma örnekleminin \%42,7'si erkek, \%53,'ü kadın (belirtilmemiş $\% 4.3$ ); $\% 27$ '2'si $20-30$, $\% 50$ 'si $31-40$ ve $\% 18,5$ 'sı 40 ve üzeri (belirtilmemiş \%4.3) yaş aralığındadır.

\subsection{Veri Toplama Aracı}

\subsection{1. Örgütsel Adalet Ölçeği}

Hoy ve Tarter (2004) tarafından geliştirilen, Taşdan ve Yılmaz (2008) tarafından Türkçe'ye uyarlanan örgütsel adalet ölçeği tek boyuttan oluşmaktadır. Taşdan ve Yılmaz'ın (2008) uyarlama çalışmasında ölçeğin tek başına açıkladığı varyansın \% 61.74 olduğu, ölçekte yer alan maddelerin faktör yük değerlerinin .44 ile .89 arasında değiştiği ve ölçeğin Cronbach Alfa güvenirlik değerinin .92 olduğu görülmüştür. Taşdan ve Yılmaz'ın (2008) uyarlama çalışmasında "Okul müdürü ön plana çıkmaya (popüler olmaya) çalışmaz." şeklinde yer alan, asıl metinde "The principal does not play favorites." olarak kullanılan ifadenin dışında kalan çeviri maddeleri olduğu gibi kullanıımıştır. Asıl metinde yer alan "play favorites" kavramının deyim anlamı tercih edildiği (http://tureng.com) için ilgili ifade "Müdür taraf tutmaz." şeklinde aslından tekrar çevrilmiştir. Bu nedenle, mevcut araştırmada ölçeğe yönelik Doğrulayıcı Faktör Analizi (DFA) analizi yapılmıştır. DFA AMOS 20.0 paket programı ile gerçekleştirilmiştir. DFA sonucu ölçeğin uyum indeksleri incelendiğinde, $\left(\chi^{2}=64.633 ; \mathrm{df}=30 ; \chi^{2} / \mathrm{df}=2.14 ; \mathrm{RMSEA}=.06\right.$; $A G F I=.93 ; \mathrm{GFI}=.96 ; \mathrm{CFI}=.99)$ ölçeğin tek faktörlü yapısının korunduğu ve ölçeğin faktör yük değerlerinin .58 ile .93 arasında değiştiği görülmüştür. $\chi^{2} / \mathrm{df}$ değerinin üçten küçük olması modelin genel uyumunun iyi olduğu sonucunu verir. RMSEA'nın sıfıra yakın olması gözlenen ve üretilen matrisler arasındaki minimum hatayı gösterir. CFI karşılaştırmalı uyum indeksidir ve indeksin bire yakın olması uyumun iyiliğine işaret eder. GFI model ile açıklanabilen varyans ve kovaryansın nispi miktarını gösteren mutlak uyum indeksidir. AGFI örneklem genişliği dikkate alınarak düzeltilmiş GFI değeridir. AGFI ve GFI 0 ile 1 arasında değer alır ve değerler .90 üzeri ise iyi uyum olduğunu gösterir (Meydan ve Şeşen, 2011). Bu araştırmada, ölçeğin Cronbach alfa değeri .94'tür. Maddelerin ayırt ediciliklerini belirlemek amacıyla madde-toplam puan korelasyonuna bakılmıştır. Bu doğrultuda, örgütsel adalet ölçeği madde toplam korelasyonları incelenmiş olup madde toplam korelasyon değerlerinin .67 ile .85 arasında değiştiği görülmüştür.

\subsection{2. İşe Yabancılaşma Ölçeği}

Ölçek, araştırmacılar tarafından geliştirilmiştir. Faktör analizi SPSS 21.0 paket programında Temel Bileşenler Tekniği kullanılarak elde edilmiştir. Ölçek maddeleri ilgili literatürden (Banai ve Reisel, 2007; Hirschfeld ve Feild, 2000; Nair ve Vohra, 2010; Elma, 2003; Hoy, Blazovsky ve Newland, 1983) yararlanılarak yazılmıştır. Ölçek geliştirme çalışması için -bu araştırmanın örneklemi dışında- ilköğretim okullarında görevli 340 öğretmene anket uygulanmıştır. Örneklemin \%51'8'i erkek, \%48'2'si kadındır. Ölçeğin faktör yapısı Açımlayııı Faktör Analizi 
(AFA) ile belirlenmiştir. Faktör analizi öncesi verilerin faktör analizi için uygunluğu ve yeterliği test edilmiştir. Bu çerçevede, Kaiser Meyer Oklin'in (KMO) ve Barlett Sphericity (BS) testlerine bakılmış, KMO değeri .94 ve BS testi değeri 2603.668 (df= $105 p=.00$ ) olarak tespit edilmiştir. $\mathrm{KMO}$ değerinin .70 ve üzeri bir değer alması verilerin AFA için uygun olduğunu gösterir (Can, 2013). Ayrıca, Barlett testi değerinin de anlamlı çıkması gerekmektedir (Bayram, 2009; Seçer, 2013).

Illk AFA sonucu, ölçeğin faktör öz değeri birden büyük iki faktörde toplandığı; birinci faktörün toplam varyansın \%49.19'unu, ikinci faktörün \%6.95'ini açıkladığı görülmüştür. Ölçeğin faktör yük değerleri incelendiğinde, on ikinci maddenin faktör yük değerinin her iki faktördeki yük değeri arasında .01'den daha küçük bir fark olduğu tespit edilmiştir. Bu nedenle, ilgili madde ölçekten çıkartılarak AFA tekrar yapılmıştır. İkinci kez yapılan AFA sonucunda, ölçeğin tek faktörde toplandığı ve bu faktörün toplam varyansın \%50.45'ini açıkladığı ortaya çıkmıştır. Tek faktöre karar verilirken Scree plot ve Kaiser'in 'öz değerlerin birden büyük olmalı' kuralı dikkate alınmıştır.

Ölçeğin güvenirlik analizinde tek ölçümün kendi içinde ne kadar tutarlı olduğunun göstergesi olan Cronbach Alfa (Can, 2013) değeri ile ölçek yarılama yöntemiyle elde edilen Spearman Brown ve Guttman Split Half güvenirlik değerine bakılmıştır. Ölçeğin güvenirlik analizinde Cronbach Alfa değeri .92; Spearman Brown .91 ve Guttman Split Half .91 olarak ortaya çıkmıştır. Ayrıca, madde toplam puan korelasyonuna da bakılmıştır. Ölçek madde toplam korelasyonu değerleri birinci maddeden on dördüncü maddeye kadar sırasıyla .62, .59, $.55, .70, .67, .67, .59, .73, .73, .79, .73, .53, .69 .43$ olarak bulunmuştur. Ölçek Likert tipinde 1'den (Kesinlikle katılmıyorum) 5'e kadar (Tamamen katılıyorum) aralıklı olacak şekilde hazırlanmıştır. Ölçekte yer alan tüm maddeler olumludur. Bu durumda, 14 maddelik yabancılaşma ölçeğinden alınacak en yüksek puan 70 , en düşük puan 14 'tür.

Bu araştırmada ölçeğin Cronbach Alfa değeri .94 olarak bulunmuştur. Ayrıca, ölçeğe yönelik DFA da yapılmıştır. DFA sonucu ölçeğin uyum indeksleri incelendiğinde, $\left(\chi^{2}=203.355 ; d f=68\right.$; $\left.\chi^{2} / \mathrm{df}=2.99 ; \mathrm{RMSEA}=.08 ; \mathrm{AGFI}=.87 ; \mathrm{GFI}=.91 ; \mathrm{CFI}=.95\right)$ ölçeğin tek faktörlü yapısının doğrulandığı söylenebilir. Ölçek maddeleri Ek 1'de verilmiştir.

\subsection{Verilerin Analizi}

Veriler SPSS 21.0 paket programı kullanılarak analiz edilmiştir. Veriler t- testi, ANOVA korelasyon ve regresyon istatistik tekniği ile analiz edilmiştir. Analize başlamadan önce ölçeklerden elde edilen verilerin normal dağııım sağlayıp sağlamadığına bakılmıştır. Normallik dağııımı için basıklık ve çarpıklık katsayıları dikkate alınmıştır. Çarpıklık ve basıklık değerleri doğrultusunda, örgütsel adalet ( $C=-.21 ; B=-1.96)$ ve işe yabancılaşma ölçeği ( $C=.31 ; B=-1.91$ ) puanlarının normalden önemli sapma göstermediği söylenebilir. Her iki ölçeğin çarpıklık ve basıklık değerinin \pm 2 aralığında kalması nedeniyle verilerin tek değişkenli normal dağılım gösterdiği söylenebilir (Ak, 2008; Bayram, 2009). Verilerin uç değere sahip olup olmadığına Mahalanobis uzaklığı ile bakılmıştır. Araştırmada bağımsız değişken sayısı bir olduğu için Mahalanobis uzaklık değeri 0.001 anlamlılık düzeyindeki kay kare tablo değeriyle $(10,83)$ karşılaştırılmıştır. Karşılaştırma sonucunda, kay kare tablo değerinde belirtilen değerden büyük olan hiçbir veri bulunmamıştır. Bu durumda, veri setinin uç değerlerden arınık olduğu söylenebilir (Çokluk, Şekercioğlu ve Büyüköztürk, 2014). Doğrusallığın belirlenmesinde ise Saçıım grafiği matrisine bakılmıştır. Saçılım grafiği matrisinde her bir değişken çiftinin saçılma diyagramlarının elips şeklinde olduğu görülmüştür. Bu nedenle, doğrusallığın sağlandığı söylenebilir (Mertler ve Vannatta, 2005 Akt: Çokluk, Şekercioğlu ve Büyüköztürk, 2014). Ayrıca, $Q-Q$ grafiği doğrultusunda, hataların normal dağılım gösterdiği; standardize edilmiş hatalar ile tahmini değerler arasında çizilen saçılma diyagramı doğrultusunda da hatalar arası eşit varyanslıığın olduğu kabul edilmiştir. ANOVA istatistiği tekniğinin kullanıldığı yerlerde gruplar arasındaki farkın kaynağını belirlemede varyanslar homojen olduğu için Post Hoc testlerinden 
Scheffe kullanılmıştır. Değişkenlerle elde edilen istatistikler .05 anlamlılık düzeyinde test edilmiştir. Araştırmaya katılan öğretmenlere ilişkin betimsel istatistikler örneklem başlığında verilmiştir. ANOVA ve $t$ - testi analizinde cinsiyet ve yaşın belirtilmediği toplam on üç anket analize alınmamıştır. Araştırmada kullanılan örgütsel adalet ve işe yabancılaşma ölçeği puanlamasında kullanılan değer aralıkları ve düzeyleri Tablo 1'de verilmiştir.

Tablo 1

Örgütsel Adalet ve Iş̧e Yabancılaşma Ölçeği Puanlamasında Kullanılan Değer Aralıkları

\begin{tabular}{ccc}
\hline Puan aralıkları & Örgütsel adalet & işe yabancilaşma \\
\hline $1,00-1,80$ & Çok düşük & Çok düšük \\
$1,82-2,60$ & Düşük & Düşük \\
$2,61-3,40$ & Kısmen yüksek & Kısmen yüksek \\
$3,41-4,20$ & Yüksek & Yüksek \\
$4,21-5,00$ & Çok yüksek & Çok yüksek \\
\hline
\end{tabular}

\section{BULGULAR} verilmiştir.

Bu bölümde, araştırmadan elde edilen bulgulara alt amaçlar doğrultusunda yer

\section{Cinsiyete göre öğretmenlerin örgütsel adalet algılarının incelenmesine ilişkin bulgular}

Cinsiyete göre öğretmenlerin örgütsel adalet algılarının anlamlı bir şekilde farklılaşıp farklılaşmadığını belirleyebilmek amacıyla t-testi yapılmış olup sonuçlar Tablo 2'de verilmiştir.

Tablo 2

Cinsiyete Göre Yapılan t-Testi Sonuçları

\begin{tabular}{cccccccc}
\hline Ölçekler & Cinsiyet & $\mathbf{N}$ & $\bar{X}$ & ss & sd & $\boldsymbol{t}$ & $\boldsymbol{p}$ \\
\hline \multirow{2}{*}{ Örgütsel adalet } & Erkek & 129 & 3.99 & .88 & \multirow{2}{*}{287} & \multirow{2}{*}{637} & \multirow{2}{*}{.52} \\
& Kadın & 160 & 3.93 & .91 & & \\
\hline $\bar{X}$
\end{tabular}

$\overline{\mathrm{X}}$ :Aritmetik ortalama

Tablo 2 incelendiğinde, cinsiyet değişkenine göre öğretmenlerin örgütsel adalet algılarının anlamlı bir şekilde farklılaşmadığı anlaşılmaktadır $(p>.05)$.

Yaşa göre öğretmenlerin örgütsel adalet algılarının incelenmesine ilişkin bulgular

Yaşa göre öğretmenlerin örgütsel adalet algılarının anlamlı bir şekilde farklılaşıp farklılaşmadığını belirleyebilmek amacıyla ANOVA testi yapılmış olup sonuçlar Tablo 3'te verilmiştir.

Tablo 3

Yaşa Göre Yapılan ANOVA Testi Sonuçları

\begin{tabular}{ccccccccc}
\hline Boyutlar & Yaş & $\mathbf{N}$ & $\bar{X}$ & ss & Sd & F & p & Farkın Kaynağı \\
\hline Örgütsel & $20-30$ & 82 & 4.14 & .83 & & & & \\
adalet & $31-40$ & 151 & 3.95 & .86 & $2 / 286$ & 3.32 & .04 & $20-30 / 41$ ve üzeri \\
& 41 ve üzeri & 56 & 3.75 & .97 & & & & \\
\hline
\end{tabular}

Tablo 3 incelendiğinde, yaş değişkenine göre öğretmenlerin örgütsel adalet algılarının anlamlı bir şekilde farklılaştığı anlaşımaktadır $(p<.05)$. Yaşa göre anlamlı bir şekilde farklılaşan örgütsel adalet algılarının 20-30 yaş aralığındaki öğretmenlerde 41 ve üzeri yaş aralığındaki öğretmenlere nazaran daha yüksek olduğu görülmektedir. 


\section{Değişkenlere illişkin Betimsel İstatistiki Bulgular}

Örgütsel adalet ve işe yabancılaşma verilerine ilişkin aritmetik ortalama, standart sapma (ss) değerlerinin yanı sıra değişkenler arası korelasyon değerleri incelenmiş olup sonuçlar Tablo 4'te verilmiştir.

Tablo 4

Değişkenlere iliş̧kin Betimleyici Istatistik ve Korelasyon Değerleri

\begin{tabular}{ccccc}
\hline Değişkenler & $\overline{\mathrm{X}}$ & ss & $\mathbf{1}$ & $\mathbf{2}$ \\
\hline Örgütsel adalet & 3.96 & .88 & - & $-.25^{*}$ \\
İşe yabancılaşma & 2,14 & .99 & - & - \\
\hline${ }^{*} p<.01$ & & & &
\end{tabular}

Tablo 4'te, örgütsel adalet değişkenin işe yabancılaşma ile anlamlı ve negatif yönde ilişkili oldukları görülmektedir. Ayrıca, örgütsel adalet düzeyinin yüksek, işe yabancılaşma düzeyinin kısmen yüksek olduğu da anlaşılmaktadır.

\section{Örgütsel Adaletin İşe yabancılaşmaya Etkisine ilişskin Bulgular}

Örgütsel adalet değişkenine göre işe yabancılaşma değişkeninin yordanmasına ilişkin Basit Regresyon Analizi sonuçları Tablo 5'te verilmiştir.

Tablo 5

Işe yabancılaşmanın Yordanmasına iliş̧kin Yapılan Regresyon Analizi Sonuçları

\begin{tabular}{cccc}
\hline Değişkenler & B & SH & $\boldsymbol{\beta}$ \\
\hline Sabit & 3,239 & 2.54 & - \\
Örgütsel Adalet & -.275 & .06 & $-.25^{*}$ \\
\hline $\mathrm{R}=-.25, \mathrm{R}^{2}=.06, \mathrm{~F}=19,389 * p<.01$ & &
\end{tabular}

Regresyon analizi sonuçları incelendiğinde, örgütsel adalet değişkenin işe yabancılaşma değişkenini anlamlı bir şekilde ( $ß=-.25 p<.01$ ) yordadığı görülmektedir. Ayrıca, örgütsel adalet değişkeninin işe yabancılaşma değişkeninin \%6'sını yordadığı görülmektedir. Bir başka ifadeyle, söz konusu değişkeninin işe yabancılaşma puanlarındaki değişimin \%6'sını açıkladığı söylenebilir.

\section{SONUÇ, TARTIŞMA VE ÖNERILER}

Araştırmada, öğretmenlerin örgütsel adalet algılarının yüksek düzeyde olduğu tespit edilmiştir. Bu araştırma sonucu ile Polat ve Celep (2008), Yılmaz (2010) ve Oğuz'un (2011) araştırma sonuçlarıyla benzerlik göstermektedir. Babaoğlan ve Ertürk'ün (2013) araştırmasında da katılımcıların dağıtımsal, işlemsel ve etkileşimsel adalet algılamalarının tüm boyutlarda yüksek düzeyde olduğu ortaya çıkmıştır. Tan (2006) ile Ünlü, Hamedoğlu ve Yaman'ın (2015) araştırmasında ise katılımcıların örgütsel adalet algıları orta düzeyde çıkmıştır. Bu araştırmanın sonuçları ile diğer araştırma sonuçları birlikte değerlendirildiğinde, öğretmenlerin örgütsel adalet algılarının en azından düşük düzeyde olmadığı söylenebilir. Öğretmenlerin örgütsel adalete ilişkin algılarının yüksek düzeyde olması, önemli ölçüde müdürün taraf tutmadığı, hiç kimseye ayrıcalıklı davranmadığı ve herkese yönelik adil bir şekilde muamele ettiğini ortaya koymaktadır. Bir başka açıdan, çok yüksek oranda olmasa da okullarda adaleti önemseyen bir yönetim erkinin olduğu söylenebilir. Zira örgütsel adalet algısının büyük oranda örgütsel yapıdan etkilenmektedir (Yılmaz, 2010). Bireyler, çalıştıkları örgütlerdeki olup biten olayları adalet açısından değerlendirmekte, örgütlerindeki çeşitli karar, düzenleme ve uygulamalardan etkilenebilmektedirler (İyigün, 2012).

Bu araştırmada, işe yabancılaşma düzeylerinin kısmen yüksek olduğu ortaya çıkmıştır. Erdem (2014) araştırmasında öğretmenlerin işe yabancılaşma düzeyinin kısmen katılıyorum düzeyinde olduğunu ortaya koymuştur. Bununla birlikte, Elma (2003) ve Çalışır'ın (2006) 
araştırmalarında öğretmenlerin nadiren düzeyinde işe yabancılaştıkları görülmüştür. Kesik ve Cömert'in (2014) araştırmasında ise işe yabancılaşma düzeyinin hiçbir zaman düzeyinde olduğu bulunmuştur. Bu araştırma sonucu ile değinilen diğer araştırma sonuçları birlikte değerlendirdiğinde, öğretmenlerin işe yabancılaşma düzeylerinin yüksek olmadığı söylenebilir. Bu durum eğitim örgütleri açısından olumlu olarak görülebilir. Zira öğretmenlerin yüksek düzeyde işe yabancılaşmaları sadece kendilerini etkilememekte aynı zamanda hem öğrenciyi hem okulu etkileyebilmektedir. İşe yabancılaşma bir bütün olarak kişinin hayatını etkilemektedir (Elma, 2003). Yıldız, Akgün ve Yıldız'a (2013) göre ise öğretmenlerin yabancılaşma hissine sahip olmaları onların mesleklerinden soğumalarına, derslere, öğrencilere ve eğitsel süreçlere karşı ilgi duymamalarına, eğitsel süreçlerden uzaklaşmalarına neden olabilir.

Cinsiyet değişkenine göre öğretmenlerin örgütsel adalet algılarının anlamlı bir şekilde farklılaşmadığı görülmüştür. Bu araştırmanın sonucu, Uğurlu (2009), Yılmaz (2010), Oğuz (2011) Ünlü, Hamedoğlu ve Yaman (2015) ile Ay ve Koç'un (2014) araştırma sonucuyla örtüşmekteyken, Polat ve Celep (2008) ile Çırak ve Atanur Baskan'ın (2015) araştırma sonucuyla örtüşmemektedir. Her iki araştırmada da erkek öğretmenlerin kadın öğretmenlere göre daha yüksek örgütsel adalet algısına sahip olduğu tespit edilmiştir. Esasında kadın öğretmenlerin erkek öğretmenlere göre daha düşük düzeyde örgütsel adalet algılarına rağmen hem erkek hem kadın öğretmenlerin örgütsel adalet algılarının anlamlı bir şekilde farklılaşmaması önemli bir sonuçtur. Geçmişten günümüze erkek egemen personel ve yönetici kadrosundan oluşan bir eğitim örgütü vardır. Bununla birlikte, toplumsal yapı itibarıyla da erkekler daha ön plandadır. Tüm bunlara rağmen, erkek ve kadın öğretmenlerin örgütsel adalet algılarının aynı düzeyde çıkması ve ortalama itibarıyla da birbirine çok yakın olması en azından ayrımcılık yapma/yapmama, taraf tutma/tutmama gibi eylemlerin cinsiyet bağlamında aynı oranda algılandığı şeklinde yorumlanabilir.

Yaş değişkenine göre öğretmenlerin örgütsel adalet algılarının anlamlı bir şekilde farklılaştığı tespit edilmiştir. Yaşa göre anlamlı bir şekilde farklılaşan örgütsel adalet algısının 20-30 yaş aralığındaki öğretmenlerde 41 ve üzeri yaş aralığındaki öğretmenlere nazaran daha yüksek olduğu görülmektedir. Yılmaz'ın (2010) araştırmasında da öğretmelerin örgütsel adalet algılarının yaşa göre değiştiği ve yaşı 21-30 aralığında olan öğretmenlerin örgütsel adalet algılarının daha yüksek olduğu görülmüştür. Ünlü, Hamedoğlu ve Yaman'ın (2015) araştırmasında yaşa göre öğretmenlerin örgütsel adalet algılarının değişmemesine rağmen genç öğretmenlerin örgütsel adalet algılarının daha yüksek olduğu tespit edilmiştir.

Örgütsel adalet değişkenin işe yabancılaşma değişkenini anlamlı bir şekilde yordadığı görülmektedir. Örgütsel adalet öğretmenlerin işe yabancılaşma düzeyinin \%6'sını anlamlı bir şekilde yordamaktadır. Bu sonuç, işe yabancılaşmayı yordayan farklı değişkenlerin de olduğunu ortaya koymaktadır. Örgütsel adalet işyerinde yabancılaşmayı belirleyen önemli bir değişken olmasına rağmen belirli beklentilerle işe gelen çalışanın beklentilerinin karşılanıp karşılanmadığının da yabancılaşmayı belirleyebildiği unutulmamalıdır (Sookoo, 2014). Bununla birlikte, işe yabancılaşmayı yordayan daha farklı değişkenlerin olduğu da görülmektedir. Olası yordayıcılar bürokrasiyi, iş özelliklerini, iş̧̧i merkeziyetçiliğini, iş kontrol eğrisini içine alabilir (Aiken ve Hage 1966; Nair ve Vohra, 2010).

Eğitim örgütleri dışında yapılan araştırmalar incelendiğinde, dağıtımsal ve işlemsel adalet ile işe yabancılaşma (Ceylan ve Sulu, 2011); işlemsel adalet ile işe yabancılaşma (Sookoo, 2014) arasında anlamlı bir ilişki olduğunu görülmektedir. Bununla birlikte, Nair ve Vohra (2010) araştırmasında dağıtımsal ve işlemsel adaletin işe yabancılaşmayı anlamlı bir şekilde yordamadığını tespit etmiştir. Sonuç olarak, dağıtımsal adaletsizlik güçsüzlük ve izolasyon hissine neden olan en etkili adaletsizlik şekli değildir. Örneğin aynı düzeyde çalıştığını 
düşündüğü bir çalışandan daha az para ya da ikramiye aldığını düşünen bir çalışan bu olumsuz durumun üstesinden gelmekte kendini güçsüz hisseder (Ceylan ve Sulu, 2014).

Örgütsel adalet çalışanların hepsinin örgüt için anlamlı ve değerli olduğunu ortaya koyan bir gerçekliktir. Adaletin sağlanmadığı, örgütün kaynaklarının adil biçimde paylaştırılmadığı, kullandırılmadığı bir ortamda öğretmen kendini dışlanmış gibi görebilir. Hajda'ya (1961) göre yabancılaşma bireyin sosyal ve kültürel katılımlardan dışlanması veya kendini dışlamasını yansıtan gergin olma veya rahat olmama hissini barındııı. Bu anlamda, adaletin olmadığı veya yetersiz olduğu ortamlarda öğretmenlerin kendini ortamdan ve işten dışlaması, rahatsız olması ve nihayetinde yabancılaşma hissi yaşaması muhtemeldir. İş ilişkilerinin doğasının yabancılaşma üzerine etkisi anlaşılabilir. Yapılandırılmış bir çevrede yeterince geniş olmamak ve kendini ifade etmede sınırlı kalmak kaydıyla kendisini analiz etmeye ve düşünmeye zorlayan bir problem üzerine çalışan bilgili bir çalışan iş ilişkileri kafasına yatmadığında kendini daha kötü hissedebilir (Nair ve Vohra, 2010).

Araştırma sonuçları, hem yöneticilere hem de araştırmacılara yönelik önemli sonuçları barındırmaktadır. Öncelikli olarak, yöneticilere öğretmenlerin işe yabancılaşmasında örgütsel adaletin önemli bir yeri olduğunu ortaya koymaktadır. Bu anlamda, yöneticilerin okulun imkanlarını tüm personele adil bir biçimde kullandırmaları, taraf tutmamaları, ayrıcalıklı muamelede bulunmamaları ve yüksek etik standartlara bağlı kalmaları gibi eylem ve uygulamaları örgütsel adalet açısından değerlendirmeleri gerekmektedir. Ki bu durum, öğretmenlerin işe yabancılaşmalarını engelleme adına yöneticilere önemli bir veri sağlamaktadır. Araştırmacılara ise farklı eğitim kademelerinde (ilkokul, ortaokul ve üniversite) örgütsel adalet ile işe yabancılaşma arasındaki ilişkinin incelenmediğini ortaya koymaktadır. Bununla birlikte, salt öğretmen düzeyinde olmayıp öğrenci düzeyinde de adalet ve yabancılaşma değişkenlerinin incelenmesi adına araştırmacılara yön vermektedir.

\section{KAYNAKLAR}

Aiken, M. ve Hage, J. (1966). Organizational alienation: A comparative analysis. American Sociological Review, 31, s. 497-507.

Ak, B. (2008). Güvenirlik Analizi. SPSS Uygulamalı Çok Değişkenli istatistik Teknikleri (Editor: Şeref Kalaycı). Ankara: Asil Yayıncılık.

Altaş, S. S. ve Çekmecelioğlu, H. G. (2015). Örgütsel adalet algısının iş tatmini, örgütsel bağılık ve iş performansı üzerindeki etkileri: Okul öncesi öğretmenleri üzerinde bir araştırma. iktisadi ve Idari Bilimler Dergisi, 29(3), s. 421-439.

Ay, G. ve Koç, H. (2014). Örgütsel adalet algısı ile örgütsel bağlılık düzeyi arasındaki ilişkinin belirlenmesi: öğretmenler üzerinde bir inceleme. İşletme Araştırmaları Dergisi, 6(2), s.67-90.

Aydın, i. ve Karaman-Kepenekçi, Y. (2008). Principals' opinions of organisational justice In elementary schools in turkey. Journal of Educational Administration, 46(4), s.497-513.

Babaoğlan, E. ve Ertürk, E. (2013). Öğretmenlerin örgütsel adalet algısı ile örgütsel adanmışlıkları arasındaki ilişki. Hacettepe Üniversitesi Eğitim Fakültesi Dergisi, 28(2), s.87-101.

Bakhshi, A., Kumar, K. ve Rani, E. (2009). Organizational justice perceptions as predictor of job satisfaction and organization commitment. International Journal of Business and Management, 4(9), s. 145-154 
Bal, V. (2014). Örgütsel adalet ve örgütsel bağlılık ilişkisi: Manisa'daki eğitim kurumlarında bir araştırma. Aksaray Üniversitesi iktisadi ve Idari Bilimler Fakültesi Dergisi, 6(1), 1-9. http://iibfdergi.aksaray.edu.tr

Banai, M. ve Reisel, W. D. (2007). The influence of supportive leadership and job characteristics on work alienation: A six-country investigation. Journal of World Business, 42. 463-476. doi:10.1016/j.jwb.2007.06.007

Baş, G. ve Şentürk, C. (2011). Illköğretim okulu öğretmenlerinin örgütsel adalet, örgütsel vatandaşlık ve örgütsel güven algıları. Kuram ve Uygulamada Eğitim Yönetimi, 17(1), s. 29-62.

Başar, U. (2011). Örgütsel adalet algısı, örgütsel özdeşleşme ve iş tatmini arasındaki ilişkilere yönelik görgül bir araştırma. Yayımlanmamış yüksek lisans tezi. Kara Harp Okulu Savunma Bilimleri Enstitüsü. Ankara.

Bayram, N. (2009). Sosyal Bilimlerde SPSS ile Veri Analizi. Ezgi Kitapevi. Bursa.

Can, A. (2013). SPSS ile Nicel Veri Analizi. Ankara: Pegem Akademi Yayınları.

Ceylan, A. ve Sulu, S. (2011). Organizational injustice and work alienation. Ekonomie a Management, 2, s. 65-78.

Choi, S. (2011). Organizational justice and employee work attitudes: The federal case. The American Review of Public Administration, 41(2) s. 185-204. DOI: 10.1177/0275074010373275

Cohen-Charash, Y. ve Spector, P. E. (2001). The role of justice in organizations: a meta-analysis. Organizational Behavior and Human Decision Processe, 86(2), s. 278-321. doi:10.1006/obhd.2001.2958

Colquitt, J. A., Conlon, D. E., Wesson, M. J., Porter, .L.H ve YEE NG, K. (2001). Justice at the Millennium: A meta-analytic review of 25 years of organizational justice research. Journal of Applied Psyhology, 86(3), s. 425-445.DOI: 10.1037//0021-9010.86.3.425

Cowherd, D. M. ve Levine, D. I. (1992). Product quality and pay equity between lowerlevel employees and top management: An investigation of distributive justice theory. Administrative Science Quarterly, 37(2), s. 302-320.

Cropanzano, R., Byrne, Z. S., Bobocel, D. R. ve Rupp, D. E. (2001). Moral virtues, fairness heuristics, social entities, and other denizens of organizational justice. Journal of Vocational Behavior, 58, s. 164-209. doi:10.1006/jvbe.2001.1791

Cüce, H., Güney, S. ve Tayfur, Ö. (2013). Örgütsel adalet algılarının örgütsel özdeşleşme üzerindeki etkisini belirlemeye yönelik bir araştırma. H.Ü. iktisadi ve idari Bilimler Fakültesi Dergisi, 31(1), s, 1-30.

Çağ, A. (2011). Algılanan örgütsel adaletin, örgütsel sinizme ve işten ayrılma niyetine etkisinin belirlenmesine yönelik bir araştırma. Yayımlanmamış Yüksek Lisans Tezi. Afyon Kocatepe Üniversitesi Sosyal Bilimler Enstitüsü. Afyonkarahisar.

Çalışır, i. (2006). Illköğretim okulu öğretmenlerinin işe yabancılaşması (Bolu ili örneği). Yüksek lisans tezi, Abant İzzet Baysal Üniversitesi. Bolu.

Çetin, B., Özgan, H. ve Bozbayındır, F. (2013). İlköğretim öğretmenlerinin örgütsel adalet ile sinizm algıları arasındaki ilişkinin incelenmesi. Uluslararası Hakemli Sosyal Bilimler EDergisi, 37, s. 1-20. http://www.akademikbakis.org 
Çırak, S. ve Atanur Baskan, G. (2015). Illköğretim okulu öğretmenlerinin örgütsel adalet algıSı (Ankara / Yenimahalle). Kastamonu Eğitim Dergisi, 23(3), s. 1091-1106.

Çokluk, Ö, Şekercioğlu, G. ve Büyüköztürk, Ş. (2014). Sosyal Bilimler Iç̧in Çok Değiş̧kenli istatistik SPSS ve LISREL Uygulamaları (íkinci Baskı). Ankara: Pegem Akademi Yayınları.

Deconnick, J. B. (2010). The effect of organizational justice, perceived organizational support, and perceived supervisor support on marketing employees' level of trust. Journal of Business Research, 63, s. 1349 -1355. doi: 10.1016/j.jbusres.2010.01.003

Deconnick, J. B. ve Stilwell, C. D. (2004). Incorporating organizational Justice, role states, pay satisfaction and supervisor satisfaction in a model of turnover intentions. Journal of Business Research, 57, s. 225 - 231. doi:10.1016/S0148-2963(02)00289-8

Demirel, Y. ve Seçkin, Z. (2011). Örgütsel adaletin bilgi paylaşımı üzerine etkisi: Illaç sektörü çalışanlarına yönelik bir araştırma. Bilig, 56, s. 99-119.

Doğan, A. (2008). Illköğretim kurumlarında örgütsel adaletin örgütsel bağlıık üzerine etkisi. Yayımlanmamış Yüksek Lisans Tezi. Elazığ: Fırat Üniversitesi Sosyal Bilimler Enstitüsü. Elazığ.

Elma, C. (2003). ilköğretim okul öğretmenlerinin işe yabancılaşması (Ankara ili örneği). Yayımlanmamış Doktora tezi. Ankara Üniversitesi Eğitim Bilimleri Enstitüsü. Ankara.

Eryılmaz, A. ve Burgaz, B. (2011). Özel ve resmi lise öğretmenlerinin örgütsel yabancılaşma düzeyleri. Eğitim ve Bilim. 36(161).

Esin, P. (1982). İş bölümü, yabancılaşma ve sosyal politika. Ankara Üniversitesi Siyasal Bilgiler Fakültesi Yayınları No: 502.

Fischer, R. 2004). Rewarding employee loyalty: An organizational justice approach. International Journal of Organisational Behaviour, 8(3).

Folger, R. ve Konovsky, M. A. (1989). Effects of procedural and distributive justıce on reactions to pay raise decisions. Academy of Management Joumal, 32(1), s. 115-130.

Fromm, E. (1973). Çağımızın özgürlük sorunu. (Çeviren: Bozkurt Güvenç). Özgür İnsan Yayınları, Ankara: Küçükesat Yayınları.

Greenberg, J. (2004). Stress fairness to fare no stress: Managing workplace stress by promoting organizational justice. Organizational Dynamics, 33 (4), s. 352-365. doi:10.1016/j.orgdyn.2004.09.003

Greenberg, J. (1986). Determinants of perceived fairness of performance evaluations. Journal of Avolied Psychology, 71(2), s. 340-342

Greenberg, J. (1990). Employee theft as a reaction to underpayment inequity: The hidden cost of pay cuts. Journal of Applied Psychology, 75(5), s. 561-568.

Güzel, B. ve Ayazlar, G. (2014). Örgütsel adaletin örgütsel sinizm ve işten ayrılma niyetine etkisi: otel işletmeleri araştırması. KMÜ Sosyal ve Ekonomik Araştırmalar Dergisi 16 (26), 133-142

Gyekye, S. A. ve Haybatollahi, M. (2014). Relationship between organizational justice and organizational safety climate: do fairness perceptions influence employee safety behaviour?. International Journal of Occupational Safety and Ergonomics, 20(2), s. 199211, DOI: $10.1080 / 10803548.2014 .11077045$ 
Hajda, J. (1961). Alienation and integration of student intellectuals. American Sociological Review, 26(4).

Hascher, T. ve Hagenauer, G. (2010). Alienation from school. International Journal of Educational Research, 49. Doi:10.1016/J.ijer.2011.03.002

Hirschfeld, R. R. ve Feild, H. S. (2000). Work centrality and work alienation: Distinct aspects of a general commitment to work. Journal of Organizational Behavior, 21.

Horowitz, I. L. (1966). On alienation and the social order. Philosophy and Phenomenological Research, 27(2), s. 230-237.

Hoy, W. K., Blazovsky, R. ve Newland, W. (1983). Bureaucracy and alienation: A comparative analysis. Journal of Educational Administration, 21 (2), s. 109 - 120. http://dx.doi.org/10.1108/eb009872

Hoy, W.. K. ve Tarter, C. J.. (2004). Organizational justice in schools: No justice without trust. International Journal of Educational Management, 18, s. 250-259.

İşcan, Ö. F. ve Sayın, U. (2010). Örgütsel adalet, iş tatmini ve örgütsel güven arasındaki ilişki. Atatürk Üniversitesi İktisadi ve Idari Bilimler Dergisi, 24(4), s. 195-216.

İyigün, N. Ö. (2012). Örgütsel adalet: Kuramsal bir yaklaşım. İstanbul Ticaret Üniversitesi Sosyal Bilimler Dergisi, 21, s. 49-64.

Kanungo, R. N. (1979). The concepts of alienation and involvement revisited. Psychological Bulletin, 86, s. 119-38.

Karasar, N. (2006). Bilimsel Araştırma Yöntemi. (19. Basım). Ankara: Alkım Yayınları.

Kesik, F. ve Cömert, M. (2014). Illköğretim okullarında görev yapan öğretmenlerin işe yabancılaşma düzeylerine ilişkin algıları. Inönü Üniversitesi Eğitim Fakültesi Dergisi, 15(1), s. 27-46.

Konovsky, M. A. (2000). Understanding procedural justice and its impact on business organizations. Journal of Management, 26(3), s. 489-511.

Lam, S. S. K., Schaubroeck, J. ve Aryee, S. (2002). Relationship between organizational Justice and employee work outcomes: A cross-national study. Journal of Organizational Behavior, 23(1), s. 1-18. http://www.jstor.org/stable/4093682

Lang, D. (1985). Preconditions of three types of alienation in young managers and professionals. Journal Of Occupational Behavior, 6 (3).

Leck, J. D., Saunders, D. M. ve Charbonneau, M. (1996). Affirmative action programs: An organizational justice perspective. Journal of Organizational Behavior, 17(1), s. 7989

Meydan, C. H. ve Şeşen, H. (2011). Yapısal Eşitlik Modellemesi AMOS Uygulamaları. Ankara: Detay Yayıncilık.

Moorman, R. H. (1991). Relationship between organizational justice and organizational citizenship behaviors: Do fairness perceptions influence employee citizenship?. Journal of Applied Psychology, 76(6), s. 845-855.

Nair, N. ve Vohra, N. (2010). An exploration of factors predicting work alienation of knowledge workers. Management Decision. 48(4). 600-615.DOI 10.1108/00251741011041373

Neetler, G. (1957). A Measure of alienation. American Sociological Review, 22(6), 670-677. 
Niehoff, B. P., ve Moorman, R. H. (1993). Justice as a mediator of the relationship between methods of monitoring and organizational citizenship behaviour. Acad Manage J., 36(6), s. $527-56$.

Oğuz, E. (2011). Öğretmenlerin örgütsel adalet algıları ile yöneticilerin liderlik stilleri arasındaki ilişki. Inönü Üniversitesi Eğitim Fakültesi Dergisi, 12(1), s. 45-65.

Owolabi, A. B. (2012). Effect of organizational justice and organizational environment on turnover intention of health workers in ekiti state, Nigeria. Research in World Economy, 3(1). doi:10.5430/rwe.v3n1p28

Örücü, E. ve Özafşarlıoğlu, S. (2013). Örgütsel adaletin çalışanların işten ayrılma niyetine etkisi: Güney Afrika Cumhuriyetinde bir uygulama. Mustafa Kemal Üniversitesi Sosyal Bilimler Enstitüsü Dergisi, 10(23), s. 335-338.

Özer, P. S. ve Urtekin, G. E. (2007). Örgütsel adalet algısı boyutları ve iş doyumu ilişkisi üzerine bir araştırma. Erciyes Üniversitesi Iktisadi Idari Bilimler Fakültesi Dergisi, 28, s. 107-125.

Özgan, H. ve Bozbayındır, F. (2011). Okullarda adil olmayan uygulamalar ve etkileri. Dicle Üniversitesi Ziya Gökalp Eğitim Fakültesi Dergisi, 16, s. 66-85.

Polat, S. (2007). Ortaöğretim öğretmenlerinin örgütsel adalet algıları, örgütsel güven düzeyleri ile örgütsel vatandaşlık arasındaki ilişki (Doktora Tezi). Kocaeli: Kocaeli Üniversitesi Sosyal Bilimler Enstitüsü. Kocaeli.

Polat, S. ve Celep, C. (2008). Ortaöğretim öğretmenlerinin örgütsel adalet, örgütsel güven, örgütsel vatandaşlık davranışlarına ilişkin algıları. Kuram ve Uygulamada Eğitim Yönetimi, 54, s. 307-331.

Seçer, i. (2013). SPSS ve LiSREL ile Pratik Veri Analizi. Ankara: Anı Yayıncılık.

Seeman, M. (1959). On the meaning of alienation. American Sociologial. Review, 24(6), s. 783791.

Selvitopu, A. ve Şahin, H. (2013). Ortaöğretim öğretmenlerinin örgütsel adalet algıları ile örgütsel bağlılıkları arasındaki ilişki. Ahi Evran Üniversitesi Kırşehir Eğitim Fakültesi Dergisi (KEFAD), 14(2), s. 171-189.

Sookoo, N. (2014). Perceptions of injustice and alienation dynamics within the workplace. Journal of the Department of Behavioural Sciences, 3(1).

Söyük, S. (2007). Örgütsel adaletin iş tatmini üzerine etkisi ve istanbul ilindeki özel hastanelerde çalışan hemşirelere yönelik bir çalışma. Yayımlanmamış Doktora Tezi. İstanbul Üniversitesi, Sosyal Bilimler Enstitüsü. İstanbul.

Tan, Ç. (2006). ilköğretim okullarında görev yapan öğretmenlerin örgütsel adalet konusundaki algıları. Yayımlanmamış yüksek lisans tezi, Fırat Üniversitesi Sosyal Bilimler Enstitüsü, Elazığ.

Taşdan, M., Oğuz, E., ve Ertan-Kantos, Z. (2006). Sınıf öğretmenlerinin örgütsel adalet algısı. Sakarya Üniversitesi Eğitim Fakültesi Dergisi, 12, s. 100-111.

Taşdan, M. ve Yılmaz, K. (2008). Organizational citizenship and organizational justice scales' adaptation to Turkish. TED Eğitim ve Bilim Dergisi, 33 (150), s. 87-96.

Tezcan, M. (1991). Toplumsal ve Kültürel Değişme (ikinci Basım). Ankara Üniversitesi Eğitim Bilimleri Fakültesi Yayınları. No: 164. Ankara. 
Titrek, O. (2009a). Okul türüne göre okullardaki örgütsel adalet düzeyi. Uluslararası Insan Bilimleri Dergisi. 6(2), 551-573.

Titrek, O. (2009b). Employees' organizational justice perceptions in Turkish schools. Social Behavior and Personality, 37(5), s. 605-620.

Uğurlu, C. T. (2009). Illköğretim Okulu Öğretmenlerinin Örgütsel Bağlılık Düzeylerine Yöneticilerinin Etik Liderlik ve Örgütsel Adalet Davranışlarının Etkisi, Doktora Tezi. İnönü Üniversitesi Sosyal Bilimler Enstitüsü Eğitim Bilimleri Anabilim Dalı.

Ünlü, Y., Hamedoğlu, M. A. ve Yaman, E. (2015). Öğretmenlerin örgütsel adalet algıları ve örgütsel sessizlik düzeyleri arasındaki ilişki. Sakarya University Journal of Education, 5(2), s. $140-157$.

Yadav, G. K. ve Nagle, Y K. (2012). Work alienation and occupational stress. Social Science International, 28 (2).

Yıldız, K., Akgün, N. ve Yıldız, S. (2013). İşe yabancılaşma ile örgütsel sinizm arasındaki ilişki. International Journal of Social Science, 6(6), s. 1253-1284, http://dx.doi.org/10.9761/JASSS1193

Yılmaz, K. ve Taşdan, M. (2009). Organizational citizenship and organizational justice in Turkish primary schools. Journal of Educational Administration, 47(1), s. 108-126.

Yılmaz, K. (2010). Devlet ortaöğretim okullarında görev yapan öğretmenlerin örgütsel adalet algıları. Kuram ve Uygulamada Eğitim Bilimleri, 10(1), s. 579-616

Yürür, S. (2008). Örgütsel adalet ile iş tatmini ve çalışanların bireysel özellikleri arasındaki ilişkilerin analizine yönelik bir araştırma. Süleyman Demirel Üniversitesi iktisadi ve Idari Bilimler Fakültesi Dergisi, 13(2), s. 295-312.

http://tureng.com/tr/turkce-ingilizce/play\%20favorites 


\section{Ek 1: Güvenirlik analizinde yer alan sıralamaya göre İşeYabancılaşma Ölçeği maddeleri}

1. İşimi sadece gelir getiren bir kaynak olarak görüyorum.

2. İşim ile ilgili yaptıklarımın anlamsız olduğunu düşünüyorum.

3. İşim bana angarya gibi geliyor.

4. Keşke başka bir iş yapıyor olsam diye düşünüyorum.

5. İşimden soğuduğumu hissediyorum.

6. Yıllar geçtikçe işimle ilgili hayal kırıklığı yaşıyorum.

7. Yaptığım işin sonucunda bir başarı hissi duymuyorum.

8. İ̧̧imi değiştirmeyi düşünüyorum.

9. Mecbur olmasam bu işte çalışmam diye düşünüyorum.

10. İşimin beni tatmin ettiğini düşünmüyorum.

11. İşimden soğuduğum için kendimi işime adapte etmekte zorlanıyorum.

12. İşyerinde zamanımı boşa geçirdiğimi düşünüyorum.

13. Çalışma heyecanımın azaldığını düşünüyorum.

14. Hayatımın sıradanlaştı̆̆ını hissediyorum.

Ölçekten çıkarılan madde: Yaptığım işin önemsiz olduğunu düşünüyorum. 


\section{SUMMARY}

It can be said that justice is one of the most important elements wherever on individual and society's life, is also a significant element in organizations where the individual spends important part of his daily life. Researches reveal that the justice perceived in the workplace influences the attitudes and behaviours of the workers. It can be said that individuals can not be indiffrent to injustice within the organizations. It is forecasted that workers believing that there isn't fair regime in their organizations connot adopt the goals and values of the organizations fully and that their contribution to their organizations can decrease is inevitable

Teachers' work alianation is a problem which can considerably effect the individual and the institution itself. Although work alienation is an attitudinal situation, it can also represent a general tendency such as responding reluctantly and in unattended manner to work environments and efforts. The Teacher who is alienated to his profession is unlikely to be useful to the students and as he thinks that he will be unsuccessful he avoids taking responsibilities.

The main purpose of this research is to examine the effect of perceived organisational justice on the levels of teachers' work alienation. In the direction of this purpose, the following sub-purposes are searched.

Do the teachers' perceptions regarding organizational justice differ significantly according to gender variable?

Do the teachers' perceptions regarding organizational justice differ significantly according to age?

Does the percieved work justice affect organizational alienation levels of teachers significantly?

302 teachers who are in charge at official high schools in Diyarbakır, Turkey constituted the sample of the study which was set with random sampling method. The data were collected with organizational justice scale and work alienation scale.

The data were analysed with t-test, ANOVA and regression statistics technic. Before analysis, the recieved datas were examined from the point of normality, linearity, homoscedastic, extreme values and missing values.

It was seen that teachers' perceptions regarding organizational justice didn't differ significantly according to gender variable. Although female teachers' perceptions regarding organizational justice are lower level than male teachers' perceptions regarding organizational justice, that both male and female teachers's teachers' perceptions regarding organizational justice didn't differ significantly is an important result. From past tom present, there is an education organization consisting of maledominant personnel and administrative staff. Besides, males are mostly in the forefront. Despite all, that fame and female teachers' perceptions regarding organizational justice are at the same level and in juxtaposition from the point of mean can be commented as acts like discrimination or nondiscrimination, siding or non-siding are perceieved evenly in the context of gender.

That the teachers' perceptions regarding organizational justice differed significantly was determined. It was seen that organizational justice perception differed significantly according to age are higher at 20-30 aged teachers than 41 aged and above teachers.

It was seen that organizational justice variable predicted work alienation variable significantly. Organizational justice predicted $\% 6$ of the level of teachers' work alienation significantly. This result showed that there are different variables predicting work alienation. Probable predictors can include bureaucracy, work features, worker centralization, work control characteristic.

Organizational justice is a reality revealing that all employees are valuable and meaningful for organization. Teachers can feel rejected themselves in an environment where the justice is not provided, sources aren't apportioned justly and used. Alienation includes that individual is marginalized from social and cultural participation or feeling of being nervous or not being ease. In this sense, it is probable that teachers isolate themselves from environment and work, feel uncomfortable and alienated in environments where the justice is inadequate or not. 
Research results has important implications for both managers and researchers. Initially, it reveals that organizational justice has on important place in the alienation of teachers. In this sense, managers should provide all the staff to use the oppurtunities of the school in a fair manner, shouldn't take sides and show preferential treatment, should adhere to high ethical standarts and they need to evaluate these situations and applications in terms of organizational justice. This situation provides important data to the managers on behalf of inhibition of teachers' work alienation. However, for researchers it reveals that the relationship between organisational justice and work alienation in different educational levels (primary, secondary and university) isn't examined. In addition to this it gives directions to the researchers to examine the variables of justice and alienation not only at the level of teacher but also at the level of student. 